\title{
Cognitive Opportunities of One Historical Document
}

\author{
Larisa V. Zandanova* \\ East Siberian State Academy of Education \\ 6 Lower Quay, Irkutsk, 664011, Russia
}

Received 12.07.2014, received in revised form 07.09.2014, accepted 09.10.2014

In the article the author studies problems of the country modernization and the related processes of agricultural collectivization and dekulakization (the peasantry dispossession of "kulaks" - wealthy peasants), which caused the necessity of planned resettlement of workforce to Eastern Siberia. The author uses office work materials, oral memoirs of the participants, the party and the government documents.

Keywords: agricultural collectivization, dispossession of kulaks, Eastern Siberia, resettlement of peasants, resettlement policy of the state.

Research area: History.

Modern problems of Siberian population disbandment during the Post-Soviet period necessitate addressing to historical experience even more often. Among the actions directed on hands inflow to eastern regions of the country, there was also planned and organized resettlement that was carried out on a voluntary basis. The resettlement policy of the Soviet state is studied insufficiently as information on migratory processes most often was secret. The source base of these processes study generally consists of official, legislative and office work documentation that allows to see the scales, direction of streams and, less often, to trace the objective reasons of resettlements and their influence on social and economic development of regions, to identify the main participants of events and to understand their vital strategy.
In the course of study the references on the subject of resettlement during the pre-war period the document, which is quite informative to clarify the circumstances of beginning the new stage of resettlement movement to Siberia in the second half of the 1930s, has been found. It is the letter of the East Siberian regional committee of AllUnion Communist Party (Bolsheviks) secretary M.O. Razumov to I.V. Stalin and V.M. Molotov with a request to allow organized resettlement to the region from the other territories of the USSR, written, how it is specified, not later than July 11, 1934. The regional committee secretary reported about a lack of manpower in the region, what constrained agricultural production development, industry and transport. He saw a solution in a planned resettlement of $25-30$ thousand country farms to the region within three years. It is written

(C) Siberian Federal University. All rights reserved

* Corresponding author E-mail address: zandanova@mail.ru 
in the letter: "For the last $3-4$ years, in connection with kulak farms liquidation, individualists and collective farmers' withdrawal from the village, and also certification ..., there is a decrease in not less than $50-60$ thousand country farms in the region. There are a large number of inhabited and economic constructions in villages that ... can be provided for migrants" (1)

The text of the letter is laconic, it occupies not more than a page, however, in the course of the careful analysis of its contents it is possible to get an idea of the events that preceded the need of Eastern Siberia leaders to address the government with a similar request, to understand the processes that took place not only in Siberia, but also in the country as a whole. Analysis of the letter's text raised a number of questions to answer which it was necessary to study other, different sources. For example:

- Why was this letter written in 1934 ?

- What districts and areas were parts of Eastern Siberia in the 1930s?

- Who was M.O. Razumov?

- What contributed to manpower shortage?

- What was the reason for farms' mass liquidation and individualists' and collective farmers' migration from the village that cleared as lot of space?

- How were installation scales determined?

The appeal to history of that period allowed to recreate a precise historical picture and, thus, to find the answer to a number of the questions raised by us. We will begin with the fact that in November, 1929 the Central Committee of AllUnion Communist Party (Bolsheviks) plenum was held which, according Stalin's article "The Year of Great Turn" set the task of continuous collectivization expansion as the primary one. In politburo(i.e.politicaldepartment) thecommission on the issues of collectivization development and its terms determination was created, and it prepared the project of the resolution about "The Rate of Collectivization and State Measures to Assist the Development of Collective Farms". The resolution adopted on January 5, 1930 gave start to collectivization acceleration and kulaks dispossession and determined rigid terms of collectivization: for a number of grain growing areas - from a year to two, for others areas in Siberia- from two to three years. It was aimed at creation of agricultural artels as the main form of collective farms. On January, 30 of the same year the Central Committee approved another resolution - "On Actions for Kulaks' Farms Liquidation of in the Areas of Continuous Collectivization", it was adopted on the basis of cruel policy concerning hundred thousands of the country families.

The precise criteria of the "kulak" category (i.e. "fist") by that time were not developed. In Siberian village there was a concept of a "prosperous peasant". According to the census carried out in spring of 1927, $6.7 \%$ of Siberian farmsteads were defined as "melkokapitalisticheskie producers" (i.e. minor capitalist). After the 15th congress they were subjected to economic abuse, therefore spring census of 1929 recorded only $1.8 \%$ of the households referred to this category (2). In this regard victims of January resolutions, in relation to who it was supposed to dispossess not less than 3 percent of the country households, became "participants of the counterrevolutionary organizations and organizers of acts of terrorism and mass counterrevolutionary actions", were referred to the first category and underwent repressions extra-judicially, according to the "troika's" decisions (i.e. extraordinary court). The other part of "kulak elements" (the second category) was recommended to be resettle from the region with their property and stock confiscation. It was supposed to resettle 50 thousand families to Siberia from the other regions (3). Prosperous 
kulak farms, which should be resettled to less convenient lands within the area, were referred to the third category.

It should be noted that collectivization of country farms in the country as a whole, and in Siberia particularly was pursued in the period of the New Economic Policy. Voluntary, on the basis of cooperation, generally the poorest farms, which were supported by the state, united in communes, agricultural associations (TOZy) or agricultural artels, that allowed them to survive and often to rise to the level of seredniak (i.e. peasants of medium welfare). However, collectivization growth rates till 1928 were slow: for example, in Irkutsk region there were about 250 country associations at this time. In the summer of 1929 collective farms of the region consisted only of $2.5 \%$ farms (4).

The accelerated rates of collectivization also defined the nature of the process: it was implemented with violation of the principle of voluntariness, with the administration facts, restriction of prosperous peasants' civil and political rights. It was not an exception, but a norm. It was noted in OGPU reports that in many areas the work on collective farms creation started with arrests, household inspections, inventories of property, what affected the rates of collectivization. Violence and repressions led to the creation of the collective farms on "paper" that broke up at the first opportunity.

Various village departments and organizations were involved in arrests during collectivization: councils, collective farms organization crews, bednyatsko-batratskie (i.e. poor and farm-labourers') groups, militia (i.e. police), OGPU, etc. All these measures caused absolutely fair protest of the peasantry which developed into mass anti-collective-farms and anti-Soviet actions. In response to them the authorities strengthened retaliatory measures and entered new sections into the Criminal code that allowed bringing wider strata of population to court. Thus, in the spring of 1930 only in one Ust'-Udinskii area 59 "kulaks" were arrested in the charge of "counterrevolutionary propaganda against collectivization and the sowing campaign“", 17 of them were condemned and sent out of the district limits. In total, at that period of time, only in Irkutsk region 5477 people were brought to trial under various articles, including 2393 people who were sent to prison, 1832 people deported, 1352 who people underwent penalties and property confiscation (5).

On February 8, 1930 on the basis of the Central Committee of All-Union Communist Party (Bolsheviks) and the Siberian Regional Committee resolutions, the resolution of Irkutsk Regional Committee of the Party that identified the main characteristics of kulak farms of the 1st, 2nd and 3rd category and provided increase in the rates of kulaks dispossession to $4-5 \%$ was adopted. According to the facts there were not so many kulaks in villages as earlier, so seredniatskie (i.e. peasants of medium welfare) farms were subjected to kulaks' dispossession.

Dispossession of kulaks peasants had the nature of expropriation of the means of production and cattle, as well as confiscation of all property up to household items everywhere. The confidential OGPU telegram to the regional committees of the party indicated inadmissibility of the similar tactics: "According to the arriving data in the course of kulaks dispossession there are rough violations of the Central Committee of regional committee directive in a number of places. In the process of kulaks dispossession, they allow looting, undress (the peasants) naked and are engaged in mockery". Some facts of expropriation of household goods, up to linen, were also noted, and in accordance to this it was said that all this occurred without higher departments' sanctions, upon the local workers' initiative (6). 
Dispossession of kulaks was also carried out in the OGPU area, and these criteria were absolutely different: retaliatory departments revealed not only prosperous peasants, but also all those who were potential enemies of the Soviet power.

Mass repressions against peasantry were carried out in parallel with economic pressure on collective farmers: strengthening of grain collections, increase of agricultural tax, obligatory insurance payments, loans repayment to the state, etc. And, without that, the high plan of delivery of bread to the state in 1930/31 was increased by 2.5 times. At the same time individualists peasants were still the main suppliers of agricultural production and money to the state.

Most tidy farms were assessed individually, without the number of family members; taxation of not agricultural income which prevailed in peasants' revenues was sharply increased. Each individual economy was exposed to self-taxation and cultural collecting on which it paid taxes for national education, health care, road management, improvements, etc. In Eastern Siberia the number of economic measures connected with kulachestvo elimination was much higher than in Western Siberia. As a result of repressions application, tax, procuring and administrative policy in Irkutsk region, $53.2 \%$ of country farms were collectivized by March 1, 1930 (7).

In the spring of 1930 the situation in Siberia was still very difficult and intense. In Eastern Siberia two thirds of all the peasants' uprisings took place in the first three months of year, and the peak of their activity - in March. The rebels put forward the slogans: "Stop with the violence. Up with free work! Up with true elective right!" In 1930 in the regional departments of OGPU 637 mass actions, 904 acts of terrorism, 419 facts of anti-Soviet leaflets distribution, numerous arsons were recorded in which a large number of bread and fodder, including collective-farm, were burned down (8).

Lawlessness and coercion in the course of collectivization incited not only a part of middle class, especially women, but also the youth against the repressive policy of the state, who were "offended" and dissatisfied with the Soviet power as well as a part of poor people "podkulachniki", i.e. considerable part of the country population.

Violent involvement into collective farms was the mass phenomenon, and the methods used by the representatives from different regions, were similar all over the country. At the meeting of Bokatui settlement dwellers, Nizhneudinsk Regional Executive Committee (RIKA) representative, the chairman of the village council and the teacher of the local school raised a question of continuous collectivization. There were representatives of 18 farms from 30 , mostly women (men were on logging), who didn't start voting for the resolution on collective farm accession. However, the next day all peasants found that they are in a collective farm and submitted applications to exit. Six poor and medium welfare peasants were arrested by the RIK authority for the refusal to enter a collective farm. The latter estimated their property and gave the order to organize collective farm on this site till 12 o'clock in the morning and to bring to his area, $12 \mathrm{~km}$ away, lists of this collective farm members, threatening to prosecute the arrested ones. The village dwellers had nothing to do but to hold a meeting in the evening at which everyone, except for three, were registered in the collective farm. The lists and the three persons who refused to enter the collective farm, were carried to the area where under threats these three persons were compelled to write declarations about agricultural artel joining (9).

In the spring months of 1930 the aspiration of prosperous peasants to "kulaks 
self-dispossession" sharply increased: they liquidated farms, exterminated cattle, destroyed grain stocks, instruments. As Z.Y. Vinokurova recollects, the inhabitant of the village of Znamenka in Zhigalovsky area, when men left the village, escaping from arrests, women began to slaughter livestock, took it away to taiga and threw to birds and animals, hoping that those who carried out kulaks dispossession would not get it (10). As a result, in Angarsky region by the end of 1930 the cattle livestock decreased in half (11).

Migration of kulaks from Siberian villages was of large scale. Often the families claimed as kulaks, went to mountains, to taiga. The most part of peasants escaping from kulaks dispossession went to the cities to the major projects and logging, where it was easier for them to get lost. For example, I.S. Kudinov, a school teacher from Znamenka in Zhigalovsky area, was subjected to dispossession due to his good financial standing, a warm shed for cattle and a well in the kitchen garden. Not waiting for his arrest, he harnessed the best horse, put necessary things and, having left his household, left the village (12). The same village dweller - Bokov, who was dispossessed because of a separator, took all his family to taiga where they lived for two years (13). In Barlukskii village council of Kuitunskii area 250 applications for exit visas issue to the gold mines of Bodaibo and on the river Aldan were submitted. In Nizhneilimskii area in 1930 all the peasants of Semakhina village ran away to Yakutsk. The dwellers of Peretolchina, Protasovi, Martynovi villages and Pezhemskoi settlement also ran away. From Zalarinsky area in March of the same year 21 families, having sold out their farms for nothing, left to an undisclosed location (14).

Prosperous families in Angarsky region were, as a rule, numerous and had much land, therefore they began to divide their farms: sons separated from their father, daughters married the poor, spouses got divorced, etc.

Thus, situation in the first months of 1930 in Eastern Siberia, as well as all over the country, was very heated. The country leaders were compelled to resort to emergency measures for peasants' war prevention: at the beginning of March they adopted a number of resolutions directed at elimination of the party line "curvatures". Stalin's article "Dizziness from Success" in which local leaders are accused of "excesses" had a big resonance. Actually it was instructed as a temporary action, for the period of sowing, to stop violent collectivization and eviction of the dispossessed. On April, 1 the bureau of the Siberian Regional Committee of All-Union Communist Party (Bolsheviks) adopted the resolution on correction "the excesses and perversions in collective-farms construction" in which the established practices of peasants' involvement to collective farms were condemned.

The measures taken quickly for the situation mitigation caused a mass exit of peasants from collective farms. Within three months in Angarsky Krai over a quarter of country farms left agricultural associations, communes and agricultural artels left; the level of collectivization decreased to the middle of May to $28 \%$ (15). The peasants, who wanted to leave collective farms, was compelled to remain in them as they couldn't return the land plots, seeds, property that had already been collectivized.

At the end of June - July, 1930 the $16^{\text {th }}$ congress of All-Union Communist Party (Bolsheviks) which toughly condemned "excesses in collectivization" took place, but in general it instructed and directed the process of peasants' associations farther, putting pressure upon kulachestvo. In Siberia the following task was set: to restore the rates achieved till spring and to bring collectivization level to $35-40 \%$, applying, thus, first of all, organizational and economic 
measures. In particular, assets withdrawal from villages went by introduction of different payments, shares, loan distribution "A five-year period in four years", repayments of actions for tractors construction, etc. Along with economic measures, great importance was attached to organizational and mass agitation work.

On July 30, 1930 Siberia was divided into two independent parts - western and eastern as well as disaggregation of Far East edge was carried out. Eastern Siberia included territories of the abolished Irkutsk, Kansk, Kirensky and Krasnoyarsk, Sretensky and Chita regions as well as Buryat Mongolsky Autonomous Soviet Socialist Republic (in the subsequent its administrative-territorial division repeatedly changed).

In December, 1930 during of the Central Committee and TSKK plenum, the decision to bring collectivization level in Siberia up to $50 \%$ was made, i.e. higher rates, than earlier (16) were set. Thus, when the main frame of the village consisting of its prosperous part was destroyed, the party and the government continued the course on "continuous collectivization", i.e. took new approach to the peasantry.

Collectivization also affected national areas where the task of transition of the nomadic peoples in the settled life was set. In Buryat region it was carried out on the most substantial scale. The resolution of CPC RSFSR dated September 6, 1930 defined the main directions in land management, collective-farm and state-farm construction. Areas of continuous collectivization Alarsky and Bokhansky aimags appeared; in Ekhirit-Bulagatsky District creation of four cattle breeding state farms was provided. Collectivization in Buryat aimags was accompanied by mass kulaks dispossession and had high rates.

The new stage of kulaks dispossession and eviction started in spring-summer of 1931.
Very high rates of collectivization encouraged optimism to the country leaders. There were even more repressions at that period of time than in spring of the previous year. There were cases when many hardworking peasants were dispossessed twice. So, on course of the Ilim River some families, resettled from their native villages rooted out taiga to make the land near their villages arable, at the Top Boyarsky stream they constructed houses and started living there. However, the authorities didn't like that "kulaks" restored and were fine, so, they were dispossessed again and sent out from the area. Constructions were appropriated, arable land was abandoned, and hunters' lodge was named Kulak vyselka (17).

Reaction of the peasantry to the same measures was similar. According to OGPU, three counterrevolutionary insurgent organizations and nine local groups (18) operated in the territory of Eastern Siberian region in the winter of 1931 spring of 1932. Western regions where even the former red guerrillas were incited against crop plans were especially volatile. Inhabitants of Tayshetsky and Nizhneudinsk regions who had the most resolute moods said that with approach of spring wouldn't sow, and would go to taiga. During this period 68 acts of terrorism, from which 28 with use of physical force were recorded in the region, 40 acts were directed against collective farms' property (19).

"Kulaks dispossession" and conduction of mass repressions against various groups of Angarsky Krai's peasantry led to destruction of the most hardworking and independent peasants' economic positions. At the same time the created collective farms and state farms in general were weak and couldn't replace individual farms' production. All this caused sharp fall of agricultural production on all types of indicators. However, while agriculture gross output and grain harvesting in 1932 were 
reduced in comparison to 1928 approximately by a quarter, bread making grew almost twice. It was explained by the fact that the state, having subordinated collective farms to it, carried out grain harvesting by surplus-appropriation system methods, taking away practically all the crop from collective-farm barns. It was the main reason of the famine that peasants experienced all the years of collectivization, but especially sharply burst out at the end of 1932.

As a result of influence of many factors that took place in the 1930s, rural population of Angarsky Krai was reduced approximately by a third, thus, cultivated areas in the middle and in the second half of the 1930s grew by $20 \%$. Workload of one collective farmer by the end of the second five-year period in eastern areas was 2-3 times higher than in the center of the country. For this reason the secretary of Eastern Siberian Regional Committee of All-Union Communist Party (Bolsheviks) addressed to the Central Committee of the Party and the government to resume planned resettlement to the regions. M.O. Razumov's destiny, who was holding this position since October, 1933, was similar to the great number of his colleagues: he was arrested and shot as enemy of the people in October, 1937.

A number of the documents revealing further actions taken for planning, organization and check of the resettlement course are stored in the Russian state archive of Eastern Siberia economy of 1934-1936. These documents contain data that in response to M.O. Razumov's letter in December, 1934 the resolution of USSR Council of People's Commissars on resettlement of 3 thousand collective farmers' families and individualists to the region from the Republic of Tatar, the Voronezh Oblast and Gorky Oblast was adopted. According to the report of the chairman of All-Union Resettlement Committee A. Muralov from all 3064 families that consisted of 15049 people who were resettled, there were $8.5 \%$ individualists' families (20). 1004 families were resettled from Tatar Autonomous Soviet Socialist Republic, 1033 families - from Voronezh Oblast, 1027 families - from Gorky Oblast. The greatest number of immigrants - 7965 people were of employable age - from 15 to 60 years. Data on qualitative structure of immigrants was also provided: there were chairmen and members of collective farms' boards, foremen, cattle breeders and collective-farms accountants, mechanics, tractor operators, combine operators, mechanics, blacksmiths, carpenters and other professions' representatives. As for national identity - the majority of the arrived were Russians, Tatars and Chuvash. Resettlements were conducted to such areas as Ziminsky, Nizhnii Udi, Zalarinsky, Tulunsky, Usolsky and Kirov, Shitkinsky, Bokhansky, Ekhirit-Bulagatsky and Alarsky aimags.

In March, 1936 A. Muralov provided the Central Committee of All-Union Communist Party (Bolsheviks) with data on placement and economic establishment of additional 3342 families in Eastern Siberia that were mostly settled in Uletovsky, Nizhnii Udi, Irkutsk, Tayshetsk, Zhigalovsk and other areas of the region (in 30 areas in general) (21). Migration process to Eastern Siberia (since 1937 its division into independent regions and areas started) proceeded up to the Great Patriotic War beginning.

The documents that are kept in the archive and are nowadays published in the collection "Eastern Vector of Resettlement Policy in the USSR. Late 1920s - late 1930s", allow to see the scope of resettlement migration to Siberian areas, to track economic establishment of the new settlers and their adaptation under the new conditions. However, all this is continuation of the research that was encouraged by the small letter of the leaders of Eastern Siberia to the party leaders and the country government. 


\section{References}

1. Russian State Archive of the Economy. F. 5675. L. 1. 79. P. 1-2.

2. Gushchin N.Ya. Class Fight and Kulachestvo Elimination as a Class. Novosibirsk, 1976. P. 105,140 .

3. Historical Archive.1994. №. 4. P. 147-152.

4. Anthology of History of Irkutsk Region. - Irkutsk, 1969. P. 261.

5. State Archive of the Irkutsk Region. F. 218. L. 3. 82. P. 225-227.

6. State Archive of Contemporary History of Irkutsk Region. F.154. L. 1. 125. P. 10, 11, 72-76.

7. State Archive of Irkutsk Region. F.218. L. 3. 89. P.3-4.

8. Tragedy of the Soviet Village. Collectivization and Dispossession of Kulaks. 1927-1939. Documents and Materials. In 5 vol. Vol. 2. November 1929 - December 1930. M., 2000. P. 790.

9. Tragedy of the Soviet Village. Collectivization and Dispossession of Kulaks. 1927-1939. Documents and Materials. In 5 vol. Vol. 2. November 1929 - December 1930. M., 2000. P. 357.

10. G.V. Afanasieva-Medvedeva's Personal Archive.

11. State Archive of the Irkutsk Region. F.218. L. 3. 91. P.42-47.

12. G.V. Afanasyeva-Medvedeva's Personal Archive.

13. G.V. Afanasyeva-Medvedeva's Personal Archive.

14. Bubnov A.S. Ilimsk Arable Land. Time of Changes. P. 1. Bratsk, 2000. P. 104.

15. Anthology of Irkutsk Region History. Irkutsk, 1969. P. 261.

16. The Peasantry of Siberia during Socialism Construction (1917-1937). - Novosibirsk, 1983. P. 238.

17. Bubnov A.S. Ilimskaya Arable Land. Time of Changes. P. 1. Bratsk, 2000. P. 138.

18. Tragedy of the Soviet Village. Collectivization and Dispossession of Kulaks. 1927-1939. Documents and Materials. In 5 vol. Vol. 2. November 1929 - December 1930. M., 2000. P. 346.

19. Tragedy of the Soviet Village. Collectivization and Dispossession of Kulaks. 1927-1939. Documents and Materials. In 5 vol. Vol. 2. November 1929 - December 1930. M., 2000. P. 348.

20. Russian State Archive of the Economy. F. 5675. L. 1. C. 79. P. 53.

21. Russian State Archive of the Economy. F. 5675. L. 1 . C. 79. P. 63-67.

22. Eastern Vector of Resettlement Policy in the USSR. Late 1920s - late 1930s. Novosibirsk, 2007. 


\section{Познавательные возможности \\ одного исторического документа}

Л.В. Занданова

Восточно-Сибирская государственная академия образования

Россия, 664011, Иркутск, ул. Нижняя Набережная, 6

В статье автор исследует проблемы модернизации страны и связанных процессов сельскохозяйственной коллективизачии и раскулачивания, которые вызвали необходимость запланированного переселения рабочей силь в Восточную Сибирь. Он использует материаль офисной работы, устные мемуары участников, партийные и правительственные документыл. Ключевые слова: Восточная Сибирь, переселение крестьян, политика государства.

Научная специальность: 07.00.00 - исторические науки. 